\title{
RESEARCH PAPER \\ Structural Equation Modeling of lifestyles and consumer attitudes towards organic food by income: a Spanish case study
}

\author{
Raquel Olivas ${ }^{1}$, Mónica Díaz ${ }^{1}$, and Rodolfo Bernabéu ${ }^{1,2}$ \\ ${ }^{1}$ Instituto de Desarrollo Regional, Universidad de Castilla-La Mancha, Campus Universitario s/n, 02071 \\ Albacete, Spain. \\ ${ }^{2}$ Escuela Técnica Superior de Ingenieros Agrónomos, Universidad de Castilla-La Mancha, Campus \\ Universitario s/n, 02071 Albacete, Spain.
}

\begin{abstract}
R. Olivas, M. Díaz, and R. Bernabéu. 2013. Structural Equation Modeling of lifestyles and consumer attitudes towards organic food by income: a Spanish case study. Cien. Inv. Agr. 40(2): 265-277. The organic food consumer in Spain is particularly conditioned by the premium prices of these foods and by their lack of availability in shops relative to conventional substitutes. In relation to the first determinant, several studies have revealed a direct relationship between maximum willingness to pay for these foods and consumer income. However, little is known about the influence of consumer attitudes, in relation to lifestyle, on these decisions. To address this issue, face-to-face surveys were conducted with 420 organic food consumers in the Madrid metropolitan area in December of 2006. The results were obtained by structural equation analysis, which includes a model for low income $\left(\chi^{2} / \mathrm{df}=2.37 \mathrm{p}<0.01\right.$, CFI $\left.=0.866\right)$ as well as high income $\left(\chi^{2} / \mathrm{df}=1.93 \mathrm{p}<0.01, \mathrm{CFI}=0.831\right)$ consumers. These individuals suggested that organic food consumption is clearly related to a healthy diet, respect for the environment and consumer sociability. Nevertheless, it must be noted that low-income consumers are more concerned about eating a healthy diet than those with higher incomes. In conclusion, the basic commercial strategy for increasing organic food consumption in Spain is tied to promoting production, favoring distribution and stimulating the competitiveness of organic food enterprises. The object is to lower its price difference with conventional food so price does not constitute an entrance barrier to this market for low income consumers.
\end{abstract}

Key words: consumer behavior, marketing strategy, structural equation modeling

\section{Introduction}

New food consumption tendencies in recent years show that consumers prefer higher quality products (Grunert, 2002), healthier items (McCluskey and Loureiro, 2003), and those that respect the

Received January 5, 2013. Accepted June 4, 2013. Corresponding author: Rodolfo.Bernabeu@uclm.es environment (Lindeman and Väänänen, 2000), and there is a growing concern about food safety (Wilcock et al., 2004).

These consumer requirements result in a demand for quality and health guarantees, especially in new products. This trend is causing agrifood businesses to adapt to satisfy such demands while simultaneously trying to become differentiated 
so they can defend their competitive status in the market.

Among the various ways agrifood businesses have to differentiate the food they produce, differentiation through the organic icon is acquiring more importance every day because it indicates that the environment is respected while growing the high quality food in question (Benbrook, 2009; Magkos et al., 2003; Bourne and Prescott, 2002).

Therefore, from a commercial standpoint, the organic characteristic can be established as an element of food differentiation (De Boer et al., 2006; Sanjuán et al., 2003; Brugarolas and Rivera, 2001) because organic food has a positive image among consumers (Mann, 2003).

Organic agriculture, which was previously considered a marginal element destined to cover a determined market segment, is experiencing growth because it offers the possibility of producing safer food, advocates an environmentally responsible attitude (this type of agriculture furthers the use of renewable resources and recycling, which restores nutrients from residual products to the soil. It respects natural mechanisms for controlling pests and disease in crops and animal husbandry while avoiding the use of pesticides, herbicides, chemical fertilizers, growth hormones and antibiotics to a great degree. Therefore, it contributes to ecosystem maintenance and reduces pollution).

Nevertheless, although the land devoted to organic agriculture in Spain has expanded remarkably in recent years, this situation has not corresponded to a noticeable increase in consumption. Therefore, exportation is practically the only outlet for organic food produced in Spain.

Because of low consumption and spending in relation to organic food among Spanish customers, the study of organic food-related consumer behavior is acquiring greater importance. Organic food expenditures during 2009 made up 1\% of the total food expenditure at 905 million Euros, or an annual expenditure of $20 €$ per capita. This outlay was higher in other European countries. According to data from 2009, Danish consumers spent the most on organic food annually, at 139 $€$ per capita. They were followed by the Swiss (132€ per capita) and Austrians (104€ per capita) (Willer and Kilcher, 2010).

It seems that specific consumer characteristics must be studied to develop different commercial solutions that will increase organic food consumption and stimulate local production as a source of income and jobs.

Within the determinants that generally seem to influence organic food consumption the most, the high price constitutes the main obstacle to purchase as well as a lack of organic food availability in commercial establishments, especially in Spain.

As a result, the maximum willingness to pay for organic food has been the object of substantial investigation. Roitner-Schobesberger et al. (2008) emphasized that consumers with a higher income have a higher probability of buying organic food. However, Millock (2002) noted that although consumers are willing, at least hypothetically, to pay a premium price for organic food, many are unwilling to pay the high price of organic food in relation to conventional food. De Magistris and Gracia (2012) came to the conclusion that people with high incomes are those who are more likely to seek out organic labels and thus, they are willing to buy organic food products. Dimitri and Dettmann (2012) indicated that households with greater access to organic food are more likely to purchase these products.

The end result of the above-mentioned papers was the discovery of a greater or lesser willingness to pay a premium for organic food compared to conventional food depending on income. However, there was no mention of consumer attitudes, as derived from their lifestyles, which led them to adopt their consumer decisions. Understanding these attitudes is the objective of this paper. 
Theoretical framework and hypothesis specification

Consumer lifestyle, which is understood as the conduct that individuals display in relation to the way they live, spend their money and use their free time, is one of the most important aspects of organic food consumption with respect to food consumer behavior (Sanjuán et al., 2003; Gil et al., 2000).

Organic food consumers in general strongly associate health with diet (Squires et al., 2001; Schifferstein and Oude Ophuis, 1998). Zanoli and Naspetti (2002) found that health is the consumer's most important motivation for buying organic food. Furthermore, Barrena and Sánchez (2010) came to the conclusion that health was one of the main components for regular consumers of organic products.

Thus, health turns out to be the main reason for buying organic food in several studies (RoitnerSchobesberger et al., 2008; Chryssohoidis and Krystallis, 2005; Yiridoe et al., 2005; Magnusson et al., 2003).

De Magistris and Gracia (2008) came to the conclusion that consumers who tried to follow a healthy diet and well-balanced lifestyle tended to have more positive environmental attitudes. They considered organic food to be healthier and higher in quality than conventional food. Royne et al. (2011) maintain that reaching different consumer groups with the appropriate strategies may translate into more positive eco-friendly behaviors and improved health for current and future generations.

From the above-mentioned research, it seems that the more interested consumers are in eating a healthy diet, the more organic food they will consume and the more conscientious they will be towards the environment. In this sense, the following can be established as a first hypothesis:
$\mathrm{H}^{1}$. Eating a healthy diet promotes respect for the environment $\left(\mathrm{H}^{\mathrm{l} a}\right)$ and the consumption of organic food $\left(\mathrm{H}^{1} b\right)$.

The socially concerned, environmentally conscious consumer appeared at the end of the 60's and beginning of the 70's of the last century, partly as a consequence of a general mistrust of industry and technology and partly as a by-product of the first petroleum crisis (Grunert and Juhl, 1995). At present, it is believed that concern for the environment and the purchase of products that respect the environment, such as organic food, are positive influences (Brugarolas et al., 2008; Sanjuán et al., 2003; Soler et al., 2002; Grankvist and Biel, 2001; Squires et al., 2001; Grunert and Juhl, 1995). According to the above, the following can be established as a second hypothesis:

$\mathrm{H}^{2}$. Respect for the environment promotes the consumption of organic food.

Bearden et al. (1989) indicated that group influence is an important determinant of individual behavior. They based this belief on product consumption as a social act that is subject to approval by leaders. This belief means that a special interpersonal influence exists within the consumer (Bandura, 1989). In this process, human expectations, beliefs and cognitive abilities are developed and modified by social influences, including family and friends (Cheah and Phau, 2005).

McCarty and Shrum (1994) stated that sociable individuals tend to be more respectful towards the environment than individualists because sociability involves group cooperation in relation to the individual.

Torjusen et al. (2001) indicated that many consumers consider social aspects in their choice of organic food, associating personal norms with specific behaviors towards the environment (Osterhuis, 1997). In turn, Sanjuan et al. (2003) indicated that 
consumer participation in society is a factor that can explain the organic food consumer lifestyle in Spain. In this vein, Chryssohoidis and Krystallis (2005) declared the existence of a strongly positive, statistically significant relationship between individual self-respect and enjoyment of life with the consumption of fresh fruit and organic vegetables. Pino et al. (2012) noted that for regular consumers of organic food, ethical self-identity affects attitudes towards organic food, as well as affecting buying intention. The third and final hypothesis of the model can be established as follows:

$\mathrm{H}^{3}$. The individual's sociability promotes respect towards the environment $\left(\mathrm{H}^{3} \mathrm{a}\right)$ and organic food consumption $\left(\mathrm{H}^{3} \mathrm{~b}\right)$.

Causal relationships between respect for the environment, healthy diet, sociability and organic food consumption are shown in Figure 1.

\section{Materials and methods}

\section{The sample}

In this study, 420 organic food consumers from the Madrid metropolitan area were surveyed during the month of December in 2006. The final questionnaire was addressed to organic food consumers as well as to potential consumers, that is, to those who are not consumers at present but who demonstrated a willingness to consume. For

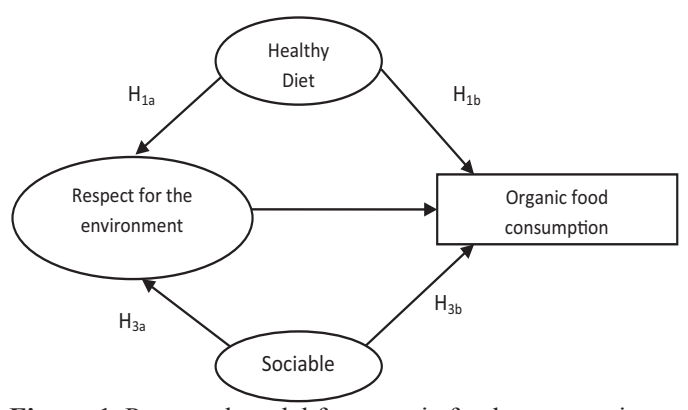

Figure 1. Proposed model for organic food consumption. the sample design, population data were taken from 2005 Community of Madrid Statistical Institute data (MCSI, 2006). Random stratified sampling was carried out by population, gender and age group (18 - 24, 25 - 34, 35 - 49, 50 - 64 and over 64 years old) for individuals who were about to buy food for their own consumption in the home. The margin of error was under $5 \%$ at a 95.5\% level of confidence $(\mathrm{p}=\mathrm{q}=0.5 ; \mathrm{k}=2)$.

Surveys were distributed in the area surrounding three hypermarkets (Alcampo, Carrefour and Hipercor) and at the market in the Ventas district, since, according to the Madrid Community Organic Agriculture Committee (MCOAC, 2006), these are the primary public organic food sales establishments. The surveys were carried out at ten different centers. Seven were located in the capital of Madrid in the districts of Moratalaz, Fuencarral, Arganzuela, Hortaleza, Latina, San Blas and Ventas and three were distributed in the surrounding municipalities of Leganes, Pozuelo and Alcobendas.

The final questionnaire was structured and divided into four sections as follows: 1) characteristics of organic food consumption, 2) purchasing attitudes (preference analysis), 3) statements about consumer lifestyles and 4) consumer socioeconomic characteristics (gender, age, education, work role, monthly family income and locality).

Organic food consumption was determined by using a 5-point Likert scale, which was dependent on consumption probability. A score of 1 corresponded to the lowest probability of consumption and 5 to the greatest.

Consumers evaluated indicators on a 7-point Likert scale in which 7 represented the highest level of agreement. The indicators $\left(\mathrm{I}_{1}-\mathrm{I}_{12}\right)$ were as follows: I try to eat low-fat food; I am concerned about my health; I try to eat food without additives; I eat fruit and/or vegetables daily; I control my salt intake; I eat red meat in moderation; I collaborate with Non-Governmental Organizations 
(NGOs); I belong to an association for the defense of nature; I prefer a vegetarian diet; I see friends frequently; I dedicate my free time to travel and practice sports regularly. These indicators have been demonstrated as valid in the determination of a consumer lifestyle, for which they are frequently used (Sánchez et al., 1998).

\section{Data analysis}

Once the greater number of significant differences (as determined by ANOVA) was verified, two groups of consumers were taken into consideration depending on their monthly family income. These groups were established by lifestyle indicators. The monthly family income level was measured as a discrete variable (low income, $<2,100 €$ per month $=1, \mathrm{n}=294$, mean $=3.58 \pm 1.70$; high income, $\geq 2,100 €$ per month $=2, \mathrm{n}=126$, mean $=3.46 \pm 1.71$ ).

A Structural Equation Modeling (SEM) approach was used to analyze the factors affecting attitudes towards organic food consumption. This approach has been selected because some of the factors influencing organic food consumption, such as healthy diet, respect for the environment and sociable lifestyles, cannot be directly observed but can be considered as latent variables measured by one or more items. An exploratory factor analysis was performed on the main components to identify latent variables.

Moreover, the SEM allows for the simultaneous analysis of the relationships between dependent and independent variables in the organic food consumption model in the same way that SEM has been used before in other agrifood product studies (Martínez-Poveda et al., 2009; De Magistris and Gracia, 2008; Yee et al., 2008; Honkanen and Verplanken, 2004).

Amos 17.0 (SPSS Inc. 2009, SPSS categories, Version 17.0. Chicago, USA) was used to apply SEM to the proposed model.
A confirmatory factorial analysis was performed by means of a multi-group or multi-sample analysis to assess the measurement model (Steenkamp and Baumgartner, 1998). The factor loading model for each indicator was constrained to remain equal throughout the groups (Byrne, 2001). Lastly, for this level of invariance, the model of salient and nonsalient factor loadings for the measurement model was verified as the same in the various segmented groups (Steenkamp and Baumgartner, 1998).

The process was carried out in two stages. In the first stage, measurement models were estimated separately before the simultaneous evaluation of measurement and structural models (Anderson and Gerbing, 1988). In the second stage, measurement models were estimated for the healthy diet, respect for the environment and sociability constructs, and organic food consumption was tracked for the observed variable. Each estimate was made simultaneously in men and women to evaluate the validity of each model.

To analyze the validity of the model, it is important to use discriminant as well as convergent validity. Discriminant validity refers to the degree of differentiation among different constructs starting from only one measurement system. It is possible to calculate the degree to which both scales are superimposed through the use of the following formula:

$$
\frac{r_{x y}}{\sqrt{r_{x x} \cdot r_{y y}}}
$$

where: $r_{x y}$ is the correlation between $x$ and $y$ $r_{x x}$ is the autocorrelation of $x$ $r_{y y}$ is the autocorrelation of $y$

Although there is no standard value for discriminant validity, a result under 0.85 indicates that it is probable that discriminant validity exists between the two scales. Therefore, both scales measure theoretically different constructs. However, convergent validity was obtained from the significant t-values associated with the loading factors. 
The parameters used for model diagnosis were as follows: the Chi-square $\left(\chi^{2}\right)\left(2 \mathrm{df}<\chi^{2} \leq 3 \mathrm{df}\right.$ acceptable fit), the root mean square error of approximation (RMSEA) $(0.05<$ RMSA $\leq 0.08$ acceptable fit), the goodness of fit index (GFI) (0.90 $\leq \mathrm{GFI}<0.95$ acceptable fit), the adjusted goodness of fit index (AGFI) $(0.85 \leq$ AGFI $<0.90$ acceptable fit) and the comparative fit index (CFI) $(0.95 \leq \mathrm{CFI}$ $<0.97$ acceptable fit). The Confirmatory Multigroup Analysis (MGCA) and the structural model (Schermelleh-Engel et al., 2003) were also considered to be indicators of the quality of fit of the model.

\section{Results and discussion}

In the proposed organic food consumption model, "Organic food consumption" is measured by one observed variable (Figure 2). An exploratory factor analysis was performed on the main components (Table 1) with a varimax rotation. Three latent variables were identified, which were significant and which explained $55.01 \%$ of the variance, healthy diet explained $27.23 \%$ of the variance, sociability explained $16.88 \%$ of the variance, and respect for the environment explained $10.89 \%$ of the variance (Table 1).

Healthy diet was measured by six observed variables related to following a healthy diet, respect for the environment was measured by three observed variables related to individual environmental conservation practices, and sociability was measured by three observed variables related to free time activities (Table 1). The differences between low- and high-income consumers with regard to the indicators that form the constructs in the model are shown in Table 2.

\section{Measurement model}

The primary parameters used to test the robustness of the construct (Hair et al., 1999) show acceptable results for the multi-group model (Table 3). The reliability of the indicator loading was acceptable (Hair et al., 1999). In turn, all $t$ values associated with loading were significant. Convergent validity was obtained, and the model's quality-of-fit measures were good. Therefore,

Table 1. Exploratory factor analysis.

\begin{tabular}{lccc}
\hline Indicators & Healthy diet & Sociability & $\begin{array}{c}\text { Respect for the } \\
\text { environment }\end{array}$ \\
\hline I try to eat low-fat food & 0.762 & 0.012 & 0.001 \\
I eat fruit and/or vegetables daily & 0.735 & 0.151 & 0.100 \\
I am concerned about my health & 0.728 & 0.077 & 0.073 \\
I control my salt intake & 0.690 & 0.066 & 0.146 \\
I try to eat food without artificial additives & 0.685 & -0.210 & 0.034 \\
I eat red meat in moderation & 0.617 & 0.163 & -0.077 \\
I see friends frequently & -0.074 & 0.819 & 0.056 \\
I dedicate my free time to travel & 0.049 & 0.752 & 0.171 \\
I practice sports regularly & 0.211 & 0.644 & 0.057 \\
I belong to an association to defend nature & -0.125 & 0.137 & 0.793 \\
I collaborate with NGOs & 0.057 & 0.137 & 0.764 \\
I prefer a vegetarian diet & 0.232 & 0.006 & 0.644 \\
\% Explained variance -Factor & 27.232 & 16.884 & 10.893 \\
\% Accumulated Explained Variance & 27.232 & 44.115 & 55.009 \\
Measure of Sampling Adequacy (Kaiser-Meyer-Olkin) & Chi-square & 598.304 & \\
Bartlett's test of sphericity & Degrees of freedom & 66 & \\
\hline
\end{tabular}




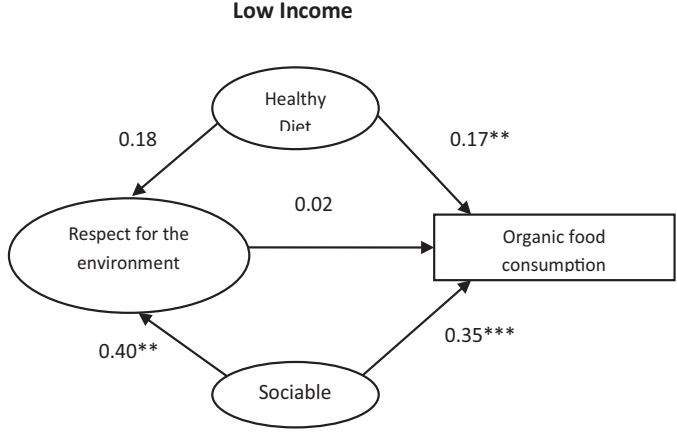

High Income

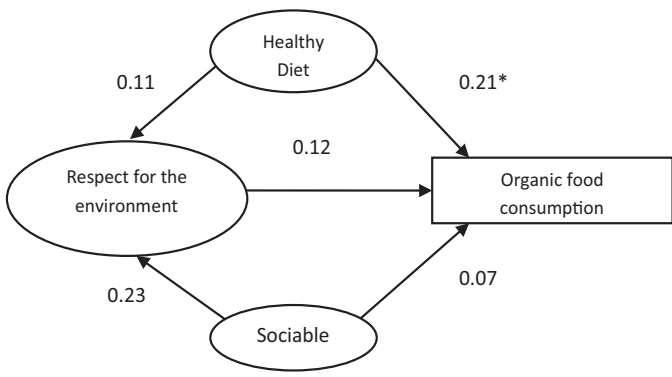

Figure 2. Group sequence diagram for low income and high income consumers.

$* * *, * *$ and $*$ indicate the existence of significant differences for a maximum error level of $0.1,1$ and $5 \%$, respectively. The values above the arrows are the standardized path coefficients and the numbers in brackets are t- values. convergent validity was considered successful and acceptable (Byrne, 2001).

Internal model consistency was obtained because the composite reliability was greater than 0.70 (Bagozzi and Yi, 1988), and composite reliability determines whether it can be assumed that a single common factor is the basis of a set of variables and substitutes Cronbach's alpha as a consequence of estimation problems in these models (Raykov, 1998); the extracted variance was over 0.50 (Hair et al., 1999) and the discriminant validity was less than 0.85 (Bagozzi and Yi, 1988).

The model yielded good fit measures for the multigroup confirmatory model, indicating that the conceptual model fit the data, as indicated by the basic rules for evaluation criteria (SchermellehEngel et al., 2003).

The Chi-square is significant (less than 3 ), $\chi^{2} / \mathrm{df}=$ 2.15 , so it is considered a good fit with the model. The root mean square error of approximation

Table 2. Descriptive statistical indicators for consumer lifestyles.

\begin{tabular}{|c|c|c|c|c|c|}
\hline \multirow[b]{2}{*}{ Construct } & \multirow[b]{2}{*}{ Indicators } & \multicolumn{2}{|c|}{$\begin{array}{c}\text { Low } \\
\text { Income }\end{array}$} & \multicolumn{2}{|c|}{$\begin{array}{c}\text { High } \\
\text { Income }\end{array}$} \\
\hline & & $\mathrm{A}^{1}$ & $\mathrm{SD}^{2}$ & $\mathrm{~A}^{1}$ & $\mathrm{SD}^{2}$ \\
\hline \multirow[t]{6}{*}{ Healthy diet $\left(\mathrm{C}_{1}\right)$} & $\mathrm{I}_{1}:$ I try to eat low-fat food & 5.00 & \pm 2.11 & 4.84 & \pm 1.90 \\
\hline & $\mathrm{I}_{2}: \mathrm{I}$ am concerned about my health ${ }^{3}$ & 5.71 & \pm 1.56 & 5.32 & \pm 1.54 \\
\hline & $\mathrm{I}_{3}:$ I try to eat food without artificial additives ${ }^{4}$ & 4.82 & \pm 2.13 & 4.25 & \pm 1.91 \\
\hline & $\mathrm{I}_{4}:$ I eat fruit and/or vegetables daily ${ }^{4}$ & 5.91 & \pm 1.58 & 5.37 & \pm 1.74 \\
\hline & $\mathrm{I}_{5}:$ I control my salt intake ${ }^{4}$ & 4.94 & \pm 2.31 & 4.05 & \pm 2.24 \\
\hline & $\mathrm{I}_{6}:$ I eat red meat in moderation ${ }^{4}$ & 5.10 & \pm 2.10 & 4.11 & \pm 2.03 \\
\hline \multirow{3}{*}{$\begin{array}{l}\text { Respect for the } \\
\text { environment }\left(\mathrm{C}_{2}\right)\end{array}$} & $\mathrm{I}_{7}:$ I collaborate with NGOs & 2.16 & \pm 2.15 & 2.02 & \pm 1.98 \\
\hline & $\mathrm{I}_{8}: \mathrm{I}$ belong to an association to defend nature & 1.31 & \pm 1.19 & 1.57 & \pm 1.60 \\
\hline & $\mathrm{I}_{9}:$ I prefer a vegetarian diet & 1.79 & \pm 1.61 & 1.60 & \pm 1.26 \\
\hline \multirow[t]{3}{*}{ Sociability $\left(\mathrm{C}_{3}\right)$} & $\mathrm{I}_{10}:$ I see friends frequently & 4.73 & \pm 2.22 & 4.64 & \pm 1.87 \\
\hline & $\mathrm{I}_{11}:$ I dedicate my free time to travel & 3.44 & \pm 2.12 & 3.55 & \pm 2.03 \\
\hline & $\mathrm{I}_{12}:$ I practice sports regularly & 4.00 & \pm 2.35 & 3.94 & \pm 2.12 \\
\hline
\end{tabular}

${ }^{1} \mathrm{~A}$ : Average; ${ }^{2} \mathrm{SD}$ : Standard deviation. ${ }^{3}$ Indicates the existence of significant differences for a maximum error level of $5 \%$.

${ }^{4}$ Indicates the existence of significant differences for a maximum error level of $1 \%$. 
(RMSEA) is less than 0.05 , which is considered a good fit. The good fit index (GFI) was 0.92 and the comparative fit index (CFI) was 0.85 , which is a good fit, with both being approximately 0.90 (Schermelleh-Engel et al., 2003). Considering the confirmatory factorial analysis for the samples from both low income and high income consumers, the good fit measures are acceptable for both models.

Lastly, the results for the group invariance analysis indicated that configural invariance was achieved for both income groups (Table 4). That is, the salient and non-salient factor loadings in the measurement model are the same for both segmented groups (Steenkamp and Baumgartner, 1998).

\section{Structural model}

The most appropriate way to test invariance across groups is to separately obtain the best model fit for each group (Byrne, 2006). In the first place, an equality test was established without equality restrictions being imposed on the parameters. Factor variances and covariances were sequentially made on the loadings, constraining them to remain equal across low and high income samples (Table 4).

Thus, the models for both low income $\left(\chi^{2} / \mathrm{df}\right.$ $=2.37 \mathrm{p}<0.01, \mathrm{CFI}=0.866)$ and high income $\left(\chi^{2} /\right.$ $\mathrm{df}=1.93 \mathrm{p}<0.01, \mathrm{CFI}=0.831)$ consumers can be considered acceptable. Both indices $\left(\chi^{2}\right.$ and CFI) were used for both income groups in determining the model acceptability by means of a multigroup fit. The results suggest the invariance of factor form, factor loadings, factor variances and factor covariances.

\section{Hypotheses verification}

With respect to the proposed hypotheses (Figure 2), hypothesis 1, "eating a healthy diet promotes respect for the environment (Hla) and the con-

Table 3. Reliability of the multigroup confirmatory factorial analysis by income.

\begin{tabular}{|c|c|c|c|c|c|c|}
\hline \multirow[b]{2}{*}{ Construct } & \multirow[b]{2}{*}{ Indicators } & \multicolumn{2}{|c|}{$\begin{array}{l}\text { Standardized loadings } \\
\quad(\mathrm{t}-\mathrm{value})^{1}\end{array}$} & \multicolumn{2}{|c|}{$\begin{array}{l}\text { Composite reliability } \\
\text { (Extracted variance) }\end{array}$} & \multirow[b]{2}{*}{$\begin{array}{c}\text { Measure of the } \\
\text { model }\end{array}$} \\
\hline & & $\begin{array}{c}\text { Low } \\
\text { Income }\end{array}$ & $\begin{array}{l}\text { High } \\
\text { Income }\end{array}$ & $\begin{array}{l}\text { Low } \\
\text { Income }\end{array}$ & $\begin{array}{c}\text { High } \\
\text { Income }\end{array}$ & \\
\hline \multirow[t]{7}{*}{$\mathrm{C} 1$} & & & & $0.97(0.84)$ & $0.96(0.82)$ & $\chi^{2}=262.04$ \\
\hline & $\mathrm{I}_{1}$ & $0.73(0.00)^{2}$ & $0.81(0.00)^{2}$ & & & \\
\hline & $\mathrm{I}_{2}$ & $0.70(8.49)^{* * *}$ & $0.76(8.04)^{* * *}$ & & & $\mathrm{df}=122$ \\
\hline & $\mathrm{I}_{3}$ & $0.68(9.31)^{* * *}$ & $0.55(5.76)^{* * *}$ & & & \\
\hline & $\mathrm{I}_{4}$ & $0.53(7.90)^{* * *}$ & $0.64(6.74) * * *$ & & & $\chi^{2} / \mathrm{df}=2.15$ \\
\hline & $\mathrm{I}_{5}$ & $0.58(8.49)^{* * *}$ & $0.52(5.33)^{* * *}$ & & & \\
\hline & $\mathrm{I}_{6}$ & $0.54(7.95)^{* * *}$ & $0.65(7.40)^{* * *}$ & & & $\mathrm{p}=0.00$ \\
\hline \multirow[t]{4}{*}{$\mathrm{C} 2$} & & & & $0.88(0.73)$ & $0.88(0.70)$ & \\
\hline & $\mathrm{I}_{7}$ & $0.61(0.00)^{2}$ & $0.64(0.00)^{2}$ & & & RMSEA $=0.052$ \\
\hline & $\mathrm{I}_{8}$ & $0.19(1.97)^{*}$ & $0.57(1.31)$ & & & \\
\hline & $\mathrm{I}_{9}$ & $0.56(3.58)^{* * *}$ & $0.45(2.40)^{*}$ & & & \\
\hline \multirow[t]{4}{*}{$\mathrm{C} 3$} & & & & $0.89(0.80)$ & $0.82(0.64)$ & $\mathrm{GFI}=0.92$ \\
\hline & $\mathrm{I}_{10}$ & $0.60(0.00)^{\mathrm{b}}$ & $0.35(0.00)^{\mathrm{b}}$ & & & \\
\hline & $\mathrm{I}_{11}$ & $0.62(4.92)^{* * *}$ & $0.91(2.85)^{* *}$ & & & \\
\hline & $\mathrm{I}_{12}$ & $0.41(4.44)^{* * *}$ & $0.28(2.94)^{* *}$ & & & $\mathrm{CFI}=0.85$ \\
\hline
\end{tabular}

$1 * * *, * *$ and $*$ indicate the existence of significant differences for a maximum error level of $0.1,1$ and $5 \%$, respectively.

${ }^{2}$ Not calculated because the value of the weights and the variance of the construct were fixed at 1.0 .

RMSEA: Root Mean Square Error of Approximation; GFI: Good Fit Index; CFI: Comparative Fit Index. 
Table 4. Fit indices for invariance tests.

\begin{tabular}{lcccccc}
\hline Models & $\chi^{2}$ & df & $\chi^{2} / \mathrm{df}$ & NNFI & CFI & RMSEA \\
\hline Low income group & 144.46 & 61 & 2.37 & 0.828 & 0.866 & 0.068 \\
High income group & 117.40 & 61 & 1.93 & 0.784 & 0.831 & 0.086 \\
Model 1: Unrestricted model & 262.04 & 122 & 2.15 & 0.812 & 0.853 & 0.052 \\
Model 2: Model 1 with factor loading restrictions & 279.66 & 134 & 2.09 & 0.822 & 0.847 & 0.051 \\
Model 3: Model with factor loading and variance & 280.16 & 136 & 2.06 & 0.827 & 0.849 & 0.050 \\
/ covariance restrictions & 17.62 & 12 & -0.06 & -0.010 & -0.006 & -0.001 \\
Model 2 - Model 1 & 18.12 & 14 & -0.09 & 0.015 & -0.004 & -0.002 \\
Model 3 - Model 1 & & & & & \\
\hline
\end{tabular}

NNFI: Non-Normed Fit Index; CFI: Comparative Fit Index; RMSEA: Root Mean Square Error of Approximation.

sumption of organic food (Hlb)", was accepted by both income groups. Zanoli and Naspetti (2002) stated that concern for health motivates the purchase and consumption of organic food. In the same way, De Magistris and Gracia (2008) came to similar conclusions when stating that those consumers who try to follow a healthy diet practice a balanced life style and tend to have more positive environmental attitudes.

However, low income consumers were more inclined towards a respect for the environment, whereas high income consumers, were more inclined toward organic food consumption.

Nevertheless, it is necessary to indicate that low income consumers are significantly more conscientious about eating a healthy diet than those with high incomes because they are more concerned about their health. This positive association between low income and a higher concern for health is possibly related to the fact that because they have fewer economic resources, they avoid possible negative health influences derived from bad eating habits. Therefore, they eat red meat in moderation, frequently consume fruit and vegetables, control their salt intake and try to eat foods without additives.

This behavior could be explained by the fact that fruits and vegetables can be found at reasonable prices in the Spanish market, especially in season. In addition, organically grown food is decreasing in price, making it more and more accessible for any pocketbook. We are aware of the traditional association between healthy behaviors, such as the frequent consumption of fruit and vegetables, and higher incomes. However, it is also true that this pattern depends greatly on the market under analysis.

Hypothesis 2, respect for the environment promotes the consumption of organic food, was accepted in both cases, although it was less important for low income consumers. High income consumers were more inclined to belong to associations for the defense of nature.

This finding corroborates and develops what has already been detected in other studies in which a positive relationship was established between environmental awareness and the consumption of organic food (Brugarolas et al., 2008; Sanjuán et al., 2003; Soler et al., 2002).

Finally, hypothesis 3, the individual's sociability promotes respect for the environment $(\mathrm{H} 3 \mathrm{a})$ and organic food consumption (H3b), was accepted by both income groups. Nonetheless, it is necessary to note that the various social situations in which higher income consumers can be found are more relevant to a respect for the environment and consumption of organic food than those of lower incomes.

This finding expands on an observation by Sanjuán et al. (2003), who indicated that consumer participation in society is a factor that can explain 
the choice of organic food and by Torjusen et al. (2001), who noted the social aspects of the consumer decisively influenced their choice of organic food.

In conclusion, organic food consumption by both low and high income consumers can be considered to be the consequence of an interaction between eating a healthy diet, respect for the environment and the individual's sociability. However, the significance of this choice is different between low and high income consumers because the availability of a larger income favors the consumption of organic food, as expected.

Nevertheless, it should be noted that low income consumers are more concerned about eating a healthy diet than those with high incomes. Perhaps this occurs because the latter think they are guaranteed the healthiest food because of the price they pay. Meanwhile, access to these higher priced foods is impossible for the lower income consumers. At the same time, low income consumers might believe that a healthy diet can be followed with conventional food and not necessarily by consuming organic food.

\section{Managerial implications}

The low consumption of organic food in Spain is mainly related to its higher price in relation to conventional food and to problems of distribution, which can be considered an effect of the higher price. The basic commercial strategy for increasing organic food consumption in Spain is by promoting production, favoring distribution and stimulating the competitiveness of organic food enterprises. The supply side objective is to reduce the price difference with conventional food so it would not constitute a barrier for new consumers to enter this market.
Only after having corrected this situation will it make any sense to carry out stimulation policies, which would address generic information campaigns to consumers on the advantages of organic food production systems on health and the environment.

Specifically, these campaigns would be conducted by means of differentiated sales promotion according to income level at the food retailers most frequented by the different types of consumers, associations and institutions. In addition, locally produced organic food consumption should be promoted there as well, because locally produced food is easier to distribute, less costly and less polluting.

\section{Limitations and future research}

Lastly, it must be noted that the limits of this study are related to the area in which field work was conducted. Although the study is considered representative of Spanish consumers, conducting similar research in other places is advisable in the future to contrast the hypotheses and the differences between consumers with different income levels. A second stage would involve the study of specific organic foods (wine, cheese, oil, tomatoes, etc.) because it is possible that results may be different depending on the food in question. Our future lines of research aim to minimize these limitations.

\section{Acknowledgements}

The authors thank the European Social Fund and the Government of Castilla-La Mancha (Spain) for supporting Research Project PBI08-0258, "Commercial Analysis of Organic Farming in Castilla-La Mancha", within the framework of the Operative Program ESF 2007-2013. 


\title{
Resumen
}

\begin{abstract}
R. Olivas, M. Díaz y R. Bernabéu. 2013. Actitud del consumidor de alimentos ecológicos en función de su nivel de renta usando Modelos de Ecuaciones Estructurales: Estudio de un caso español. Cien. Inv. Agr. 40(2): 265-277. El consumidor de alimentos orgánicos en España está especialmente condicionado por el alto precio de estos alimentos en comparación con sus sustitutos convencionales y por su falta de disponibilidad en las tiendas. En relación con el primer determinante, varios trabajos han puesto de manifiesto la relación directa que existe entre la máxima disposición al pago por estos alimentos y los ingresos de los consumidores. Pero poco se sabe acerca de la influencia de las actitudes de los consumidores, derivadas de sus estilos de vida. Para solucionar este problema, se realizaron 420 entrevistas personales a los consumidores de alimentos en el área metropolitana de Madrid en diciembre de 2006. Los resultados, obtenidos a través de modelos de ecuaciones estructurales, que se pueden considerar aceptables, tanto en el modelo de bajos ingresos $\left(\chi^{2} / \mathrm{df}=2.37 \mathrm{p}<0,01, \mathrm{CFI}=0,866\right)$ como en el de altos ingresos $\left(\chi^{2} / \mathrm{df}=1,93 \mathrm{p}<0,01, \mathrm{CFI}=0,831\right)$, sugieren que el consumo de alimentos orgánicos está claramente relacionado con una dieta saludable, respeto por el medio ambiente y la sociabilidad de los consumidores. Sin embargo, es preciso señalar que son los consumidores con renta baja los más preocupados por seguir una dieta saludable que los de renta alta. En conclusión, la estrategia comercial básica para aumentar el consumo de alimentos ecológicos en España debería basarse en promocionar la producción, favoreciendo la distribución y estimulando la competitividad de las empresas de alimentos orgánicos, para que el precio no constituya una barrera de entrada a este mercado para los consumidores de bajos ingresos.
\end{abstract}

Palabras clave: Comportamiento del consumidor, modelos de ecuaciones estructurales, estrategia de marketing.

\section{References}

Anderson, J.C., and D.W. Gerbing. 1988. Structural equation modelling in practice: A review and recommended two-step approach. Psychol. Bull. 103: 411-423.

Bagozzi, P., and Y. Yi. 1988. On the evaluation of structural equation models. J. Acad. of Market. Sci. 16:74-94.

Bandura, A. 1989. Social Cognitive Theory. In: Vasta R. (ed.). Annals of Child Development. Jai Press LTD, Greenwich, Conn., USA. 244 pp.

Barrena, R., and M. Sánchez. 2010. Frequency of consumption and changing determinants of purchase decision: from attributes to values in the organic food market. Spanish Journal of Agricultural Research 2010 8:251-272

Bearden, W.O., R.C. Netemeyer, and J.E. Teel. 1989. Measurement of Consumer Susceptibility to Interpersonal Influence. J. Consum. Res. 15:473-481.
Benbrook, C. 2009. The impacts of yield on nutritional quality: Lessons from organic farming. HortScience 44:12-14.

Bourne, D., and J. Prescott. 2002. A Comparison of the Nutritional Value, Sensory Qualities, and Food Safety of Organically and Conventionally Produced Foods. Crit. Rev. Food Scic. Nutr. 42:1-34.

Brugarolas, M., and L.M. Rivera. 2001. Comportamiento del consumidor valenciano ante los productos ecológicos e integrados. Rev. Estud. Agrosoc. Pesqu. 192:105-121.

Brugarolas, M., R. Bernabéu, A. Martínez-Poveda, L. Martínez-Carrasco, and M. Díaz. 2008. Herramientas para la aceptación de un vino ecológico: Health claims and green claims. XXXIst World Congress of Vine and Wine. International Organisation of Vine and Wine. June 15-20. Verona, Italia.

Byrne, B.M. 2001. Structural equation modeling with AMOS. Lawrence Erlbaum Associates, Inc., Mahwah, NJ, USA. 338 pp. 
Byrne, B.M. 2006. Structural equation modeling with EQS: Basic concepts, applications and programming (2nd ed.). Erlbaum, Mahwah, NJ, USA. 440 pp.

Cheah, I., and I. Phau. 2005. Toward a framework of consumers' willingness to purchase environmentally friendly products: A study of antecedents and moderator. In: Purchase, S. (ed.). Broadening the boundaries. Univ. of Western Australia. pp: 39-46.

Chryssohoidis, G.M., and A. Krystallis. 2005. Organic consumers' personal values research: testing and validating the list of values, LOV scale and implementing a value-based segmentation task. Food Qual. Prefer. 16:585-599.

De Boer, J., M. Helms, and H. Aiking. 2006. Protein consumption and sustainability: diet diversity in EU-15. Ecol. Econ. 59:267-274.

De Magistris, T., and A. Gracia. 2008. The decision to buy organic food products in Southern Italy. British Food Journal 110:929-947.

De Magistris, T., and A. Gracia. 2012. Do Consumers Pay Attention to the Organic Label When Shopping Organic Food in Italy? In: Reed, M. (ed.). Organic Food and Agriculture - New Trends and Developments in the Social Sciences. InTech, Bristol, UK. p. 109-128

Dimitri, C., and R.L. Dettmann. 2012. Organic food consumers: what do we really know about them? British Food Journal 114:1157-1183

Gil, J.M., A. Gracia, and M. Sánchez. 2000. Market segmentation and willingness to pay for organic products in Spain. Int. Food Agribus. Manage. Rev. 3:207-226.

Grankvist, G., and A. Biel. 2001. The importance of beliefs and purchase criteria in the choice of eco-labeled food products. J. Environ. Psychol. 21:405-410.

Grunert, K.J. 2002. Current issues in the understanding of consumer food choice. Trends Food Sci. Tech. 13(8):275-285.

Grunert, S.C., and H.J. Juhl. 1995. Values, environmental attitudes and buying of organic food. J. Econ. Psychol. 16:39-62.

Hair, J., E. Anderson, R. Tathan, and W. Black. 1999. Análisis Multivariante. Prentice Hall Iberia, Madrid. $832 \mathrm{pp}$.
Honkanen, P., and B. Verplanken. 2004. Understanding attitudes towards genetically modified food: the role of values and attitudes strength. J. Consum. Policy 27:401-420.

Lindeman, M., and M. Väänänen. 2000. Measurement of ethical food choice motives. Appetite 34:55-59.

Magkos, F., F. Arvaniti, and A. Zampelas. 2003. Organic food: nutritious food or food for thought? A review of the evidence. Int. J. Food Sci. Nutr. 54(5):357-371.

Magnusson, M.K., A. Arvola, U.K. Hursti, L. Aberg, and P.O. Sjödén. 2003. Choice of organic food is related to perceived consequences for human health and to environmentally friendly behaviour. Appetite 40:109-117.

Mann, S. 2003. Why organic food in Germany is a merit good. Food Policy 28:459-469.

Martínez-Poveda, A., M. Brugarolas, F.J. Del Campo, and L. Martínez-Carrasco. 2009. Consumer-perceived risk model for the introduction of genetically modified food in Spain. Food Policy 34:519-528.

McCarty, J.A., and L.G. Shrum. 1994. The recycling of solid wastes: personal values, value orientations and attitudes about recycling as antecedents of recycling behaviour. J. Bus. Res. 30:53-62.

McCluskey, J.J., and M.L. Loureiro. 2003. The consumer response to food labelling [on line]. Discussion Paper. FAMPS Conference. Washington DC. March 20-21. Available online at: http:// www.farmfoundation.org/projects/03-65McCluskeyLoureiropaper.htm (Website accessed: July 14, 2009).

MCOAC. 2006. Datos estadísticos. Madrid Community Organic Agriculture Committee (MCOAC). Available online at: http://www.caem.es/estadisticas.htm (Website accessed: September 3, 2006).

MCSI. 2006. Estructura y evolución de la población. Madrid Community Statistical Institute (MCSI). Available online at: http://www.madrid.org/ iestadis (Website accessed: September 11, 2006).

Millock, K. 2002. Willingness to pay for organic food: a comparison between survey data and panel data from Denmark. Second World Con- 
gress of Environmental and Resource Economists, Monterey, USA, June.

Osterhuis, T.L. 1997. Pro-social consumer influence strategies: when and how do they work? J. Marketing 61: 16-29.

Pino, G., A.M. Peluso, and G. Guido. 2012. Determinants of Regular and Occasional Consumers' Intentions to Buy Organic Food. Journal of Consumer Affairs, Spring 2012: 157-169.

Raykov, T. 1998. Coefficient alpha and composite reliability with interrelated nonhomogeneous items. Appl. Psychol. Measure. 22:375-385.

Roitner-Schobesberger, B., I. Darnhofer, S. Somsook, and C.R. Vogl. 2008. Consumer perceptions of organic food in Bangkok, Thailand. Food Policy 33:112-121.

Royne, M.B., L. Marian, and J. Martinez. 2011. The Public Health Implications of Consumers' Environmental Concern and Their Willingness to Pay for an Eco-Friendly Product. The Journal of Consumer Affairs 45:329-343.

Sánchez, M., I. Grande, J.M. Gil, and A. Rodríguez. 1998. Evaluación del potencial de Mercado de los productos de agricultura ecológica. Revista de Investigación de Marketing. ESIC. Marzo. pp. 135-150.

Sanjuán, A.I., M. Sánchez, J.M. Gil, A. Gracia, and F. Soler. 2003. Brakes to organic market enlargement in Spain: consumers' and retailers' attitudes and willing to pay. Int. J. Consum. Stud. 27:134144.

Schermelleh-Engel, K., H. Moosbrugger, and H. Müller. 2003. Evaluating the fit of structural equation models: tests of significance and descriptive goodness-of-fit measures. Methods of Psychological Research 8:23-74.

Schifferstein, H.N.J., and P.A.M. Oude Ophuis. 1998. Health related determinants of organic food consumption in the Netherlands. Food Qual. and Prefer. 9:119-133.
Soler, F., J.M. Gil, and M. Sánchez. 2002. Consumers' acceptability of organic food in Spain: results from an experimental auction market. British Food Journal 104(8):670-687.

Squires, L., B. Juric, and T. Bettina-Cornwell. 2001. Level of market development and intensity of organic food consumption: cross-cultural study of Danish and New Zealand consumers. J. Consum. Market. 18(5):392-409.

Steenkamp, J.B., and H. Baumgartner. 1998. Assessing measurement invariance in crossnational consumer research. J. Consum. Res. 25:78-90.

Torjusen, H., G. Lieblein, M. Wandel, and C.A. Francis. 2001. Food system orientation and quality perception among consumers and producers of organic food in Hedmark County, Norway. Food Qual. Prefer. 12(3):207-216.

Wilcock, A., M. Pun, J. Khanona, and M. Aung. 2004. Consumer attitudes, knowledge and behaviour: a review of food safety issues. Trends Food Sci. Tech. 15:56-66.

Willer, H., and L. Kilcher. 2010. The world of organic agriculture. Statistics and emerging trends 2010. International Federation of Organic Agriculture Movements IFOAM. Available online at: http://www.organic-world.net/yearbook-2010. html (Website accessed: May 20, 2013).

Yee, W., W.B. Traill, J.L. Lusk, S.R. Jaeger, L.O. House, M. Moore, J.L. Morrow, and C. Valli. 2008. Determinants of consumers ' willingness to accept GM foods. Int. J. Biotechnol. 10(2/3):240259.

Yiridoe, E., S. Bonti-Ankoma, and C. Ralph. 2005. Comparison of consumer perceptions and preference toward organic versus conventionally produced foods: a review and update of the literature. Renew. Agric. Food Syst. 20:193-205.

Zanoli, R., and S. Naspetti. 2002. Consumer Motivations in the purchase of organic food: a means-end approach. British Food Journal 104(8):643-653. 
